\title{
PERLINDUNGAN HUKUM TERHADAP KONSUMEN DARI PRAKTIK KLINIK KECANTIKAN ILEGAL DI KARAWANG
}

\author{
Rani Apriani \\ Fakultas Hukum, Universitas Singaperbangsa Karawang \\ Jl. H.S. Ronggowaluyo Telukjambe Karawang 41361 \\ Telepon +62267 641177, Fax: +62641367 \\ Email: rani88_fhunsika@yahoo.com
}

\begin{abstract}
The beauty industry such as beauty clinics is growing rapidly in Indonesia. At present many illegal beauty clinics have sprung up in Karawang Regency, this clinic uses and / or circulates pharmaceutical preparations in the form of cosmetics and medical devices without marketing authorization from authorized institutions. What is the legal protection of consumers from illegal beauty clinic practices in Karawang? The method used in this study is the legal sociology approach (SocioLegal Approach). Legal protection for consumers who experience losses from illegal beauty clinic practices that provide and / or circulate pharmaceutical preparations in the form of cosmetics and medical devices without marketing licenses is realized through the granting of rights to claim compensation to business actors and the right to proper legal settlement through BPSK or through public justice if the business actor is not willing to provide compensation as stipulated in the Health Law and PK Law.
\end{abstract}

Keywords: Beauty Clinic, Illegal, Consumer Protection, Circular Permit

\begin{abstract}
ABSTRAK
Industri kecantikan seperti klinik kecantikan bertumbuh pesat di Indonesia. Saat ini banyak klinik kecantikan illegal yang bermunculan di Kabupaten Karawang, klinik ini menggunakan dan/atau mengedarkan sediaan farmasi berupa kosmetika dan alat kesehatan tanpa izin edar dari lembaga yang berwenang. Bagaimana perlindungan hukum terhadap konsumen dari praktik klinik kecantikan illegal di Karawang? Metode yang digunakan dalam penelitian ini adalah pendekatan sosiologi hukum (Socio-Legal Approach). Perlindungan hukum terhadap konsumen yang mengalami kerugian dari praktik klinik kecantikan illegal yang menyediakan dan/atau mengedarkan sediaan farmasi berupa kosmetika dan alat kesehatan tanpa izin edar diwujudkan dengan adanya pemberian hak untuk menuntut ganti rugi kepada pelaku usaha dan hak atas penyelesaian hukum yang patut baik melalui BPSK maupun melalui peradilan umum apabila pelaku usaha tidak bersedia untuk memberikan ganti rugi sebagaimana telah diatur dalam UU Kesehatan dan UU PK. Kata Kunci: Klinik Kecantikan, Ilegal, Perlindungan Konsumen, Izin Edar
\end{abstract}




\section{PENDAHULUAN}

Konsep kecantikan seseorang di daerah tertentu boleh jadi berbeda dari konsep kecantikan seseorang di daerah lain. ${ }^{1}$ Kecantikan adalah anugerah terindah bagi wanita. Kecantikan memiliki kemampuan magnetik luar biasa yang mampu meruntuhkan dunia laki-laki. Kecantikan secara fisik dapat membuat seorang wanita merasa percaya diri sepenuhnya dalam bergaul di lingkungannya, untuk itu wanita tidak hanya mengandalkan kecantikan fisik yang dibawa sejak lahir, namun perlu ditunjang dengan melakukan perawatan yang terbaik untuk dirinya melalui pusat perawatan kecantikan yang ada agar selalu berpenampilan cantik dan menarik.

Pandangan mengenai pentingnya merawat tubuh dalam memenuhi konsep kecantikan terus-menerus digencarkan lewat beberapa media massa dengan citraan-citraan dan realitas-realitas yang semu namun tampak nyata. Keterpa-duan antara tubuh dan kosmetik yang dilekatkan kepada perempuan mengha-silkan sebuah tanda baru yaitu kecantikan.

Fenomena yang berkembang seka-rang memandang bahwa masalah kecantikan adalah salah satu kebutuhan pokok yang pada saat tertentu harus dipenuhi baik oleh kaum wanita maupun pria. Keadaan tersebut diperkuat dengan adanya sifat manusia yang mudah meniru kelompok referensi yaitu kelompok sosial yang menjadi ukuran seseorang (bukan anggota kelompok) untuk membentuk kepribadian dan perilakunya. ${ }^{2}$ Perilaku konsumen seperti ini menyebabkan kebutuhan akan kecantikan yang meluas dikalangan masyarakat, baik dikota-kota besar maupun di kota-kota kecil seperti Karawang. Melihat kenyataan tersebut, maka konsekuensi yang kemudian muncul adalah banyak bermunculan klinik jasa kecantikan yang menawarkan berbagai macam perawatan wajah dan badan secara keseluruhan. Perkembangan klinikklinik jasa kecantikan ini diiringi dengan meningkatnya kebutuhan ma-syarakat akan kecantikan yang semakin beragam.

Saat ini, usaha kecantikan di Indonesia sudah mencapai ratusan ribu. Begitu pula di Karawang, saat ini banyak sekali dijumpai klinik kecantikan. Jenis usaha klinik ini beragam, bukan hanya klinik kecantikan dan pasar produk perawatan kulit, tetapi juga spa. Industri spa di Karawang sudah berkembang cukup luas dari tahun ke tahun dan menunjukkan pertumbuhan yang me-ningkat. Peningkatan tersebut membuat persaingan industri kecantikan menjadi salah satu peluang yang dapat meningkatkan pendapatan. Oleh karena itu, banyak pelaku usaha yang berusaha memenuhi

1 Olivia, Definisi Kecantikan, http://digilib.unila.ac.id/11921/16/BAB\%20II.pdf, 23 Oktober 2018, pukul 13.12 WIB.

2 Basu Swastha dan Hani Handoko, Manajemen Perusahaan Analisa Perilaku Konsumen, Yogyakarta: Liberty Edisi Pertama. Hlm 68 
kebutuhan akan kecantikan dengan berbagai macam inovasi.

Konsumen yang keberadaannya sa-ngat tidak terbatas dengan strata yang sangat bervariasi menyebabkan pelaku uasaha melakukan kegiatan pemasaran dan distribusi produk barang atau jasa dengan cara seefektif mungkin agar dapat mencapai konsumen yang sangat majemuk tersebut. Untuk itu semua cara pendekatan diupayakan sehingga mungkin menimbulkan berbagai dampak termasuk keadaan yang menjurus pada tindakan yang bersifat negatif bahkan tidak terpuji yang berawal dari itikad buruk. Dampak buruk yang lazim terjadi antara lain menyangkut kualitas, atau mutu barang dan jasa, informasi yang tidak jelas bahkan menyesatkan, pemalsuan dan sebagainya.

Salah satu contohnya adalah pelaku usaha di Kabupaten Karawang yang mendirikan klinik kecantikan tanpa izin dari Pemerintah Daerah dan Dinas Kesehatan. Selain itu, klinik kecantikan tersebut juga menyediakan dan/atau mengedarkan sediaan farmasi berupa kosmetika dan alat kesehatan yang di impor dari luar negeri tanpa ada izin edar dari $\mathrm{Ke}$ menterian Kesehatan dan Badan Pengawas Obat dan Makanan. Adapun Konsumen yang menggunakan produk dan jasa dari klinik kecantikan tersebut mengaku mengalami kerugian fisik berupa pembengkakan pada bagian wajahnya akibat penggunaan kosmetika dan alat kesehatan suntik dan laser dari klinik kecantikan tersebut.
Permasalahan ini sebenarnya telah diatur dalam UU No. 36 Tahun 2009 tentang Kesehatan (untuk selanjutnya disebut UU Kesehatan), Undang-Undang No. 8 Tahun 1999 Tentang Perlindungan Konsumen (untuk selanjutnya disebut UU PK), Peraturan Pemerintah No. 72 Tahun 1998 Tentang Pengamanan Sediaan Farmasi dan Alat Kesehatan (untuk selanjutnya disebut PP PSFAK), dan dalam Peraturan Menteri Kesehatan No. 9 Tahun 2014 Tentang Klinik (untuk selanjutnya disebut Per-menkes Klinik). Menurut Pasal 25 ayat (1) Permenkes Klinik, untuk mendirikan sebuah klinik, pelaku usaha harus memiliki izin mendirikan dan izin operasional.

UU Kesehatan mengatur ketentuan mengenai sediaan farmasi dan alat kesehatan yang diedarkan kepada masyarakat dimana dalam Pasal 98 ayat (1) UU Kesehatan dikatakan bahwa: "Sediaan farmasi dan alat kesehatan harus aman, berkhasiat/bermanfaat, bermutu, dan terjangkau". Rumusan dalam pasal tersebut diperkuat dalam pasal 106 ayat (1) yang mengatakan bahwa: "Sediaan Farmasi dan alat kesehatan hanya dapat diedarkan sete-lah mendapat izin edar".

Selain UU Kesehatan, UU PK juga mengatur mengenai hak-hak yang dimiliki oleh konsumen seperti yang termuat dalam pasal 4 huruf a, di-antaranya adalah hak atas kenyamanan, keamanan dan keselamatan dalam mengkonsumsi barang dan/atau jasa. 
Selain itu dalam pasal 4 huruf c juga diatur bahwa, konsumen memiliki hak atas informasi yang benar, jelas, dan jujur mengenai kondisi dan jaminan barang dan/atau jasa. Sebaliknya Pasal 7 huruf b UU PK menyebutkan bahwa Pelaku Usaha berkewajiban untuk memberikan informasi yang benar, jelas dan jujur mengenai kondisi dan jaminan barang dan/atau jasa serta pasal 7 huruf d yang menyebutkan bahwa pelaku usaha wajib untuk menjamin mutu barang dan/atau jasa yang diproduksi dan/atau diperdagangkan sesuai dengan ketentuan standar mutu barang dan/atau jasa yang berlaku.

Tanggung jawab pembayaran ganti kerugian yang dialami oleh konsumen sebagai akibat penggunaan produk didasarkan pada beberapa ketentuan yaitu berdasarkan wanprestasi dan perbuatan melawan hukum. ${ }^{3}$ Ganti kerugian yang diperoleh karena adanya wanprestasi merupakan akibat tidak dipenuhinya kewajiban utama atau kewajiban tambahan yang berupa kewajiban atas prestasi utama atau kewajiban jaminan/garansi dalam perjanjian sedangkan tuntutan ganti kerugian yang didasarkan pada perbuatan melawan hukum tidak perlu didahului dengan perjanjian sehingga tuntutan ganti kerugian dapat dilakukan oleh setiap pihak yang dirugikan, walaupun tidak pernah terdapat hubungan perjanjian antara pelaku usaha dengan konsumen.

Untuk dapat menuntut ganti kerugian, maka kerugian tersebut harus merupakan akibat dari perbuatan melanggar hukumsebagaimana yang telah diatur dalam Pasal 1365 KUH Perdata yang menyebutkan bahwa: "Setiap perbuatan yang melawan hukum yang membawa kerugian kepada seorang lain mewajibkan orang karena salahnya menerbitkan kerugian ini mengganti kerugian tersebut".

Hal tersebut berarti, untuk dapat menuntut ganti kerugian harus dipenuhi unsur-unsur sebagai berikut, adanya perbuatan melanggar hukum, adanya kerugian, adanya hubungan kausalitas antara perbuatan melanggar hukum dan kerugian, adanya kesalahan. ${ }^{4}$

Sehubungan dengan kerugian yang dialami oleh seorang konsumen jasa pelayanan kesehatan, Pasal 58 ayat (1) UU Kesehatan telah mengatur bahwa: "Tenaga kesehatan, dan/atau penye-lenggara kesehatan wajib bertanggung jawab apabila ada pasien atau konsumen yang menderita kerugian akibat kesalahan dan kelalaiannya".

Selain itu, Pasal 19 ayat (1) UU PK juga telah mengatur bahwa: "Pelaku usaha wajib bertanggung jawab mem-berikan ganti rugi atas kerusakan, pencemaran, dan atau kerugian konsumen akibat mengkonsumsi barang

\footnotetext{
3 Ahmadi Miru dan Sutarman Yodo, (2011), Hukum Perlindungan Konsumen, Jakarta: Raja Grafindo Persada, hlm. 126

4 Ibid.
} 
dan atau jasa yang dihasilkan atau diperdagangkan".

Berdasarkan uraian diatas, maka penulis tertarik untuk mengambil judul mengenai:

\section{"PERLINDUNGAN HUKUM TER-} HADAP KONSUMEN DARI PRAKTIK KLINIK KECAN-TIKAN ILEGAL DI KARAWANG", dengan rumusana masalah Bagaimana perlindungan hukum terhadap konsu-men dari praktik klinik kecantikan illegal di Karawang?.

Metode yang digunakan dalam penelitian ini adalah pendekatan sosiologi hukum (socio-legal approach) karena permasalahan yang diteliti ini didekati dari masyarakat selaku pelaku usaha dan konsumen, hukum, perlindungan konsumen, serta klinik kecantikan ilegal sedangkan spesifikasi penelitian yang digunakan berupa penelitian deskriptif yang artinya prosedur pemecahan masalah yang diteliti dengan menggambarkan objek dan subjek hukum pada saat sekarang berdasarkan fakta-fakta yang ada.

Untuk memperoleh informasi atau data yang akurat, yang berkaitan dan relevan dengan permasalahan dan penyelesaian penelitian ini, maka dipilih lokasi penelitian yaitu Karawang dengan pihak pelaku usaha yaitu klinik kecantikan yang ada di Karawang. Selain pihak pelaku usaha di atas, penulis juga melakukan penelitian pada pihak konsumen yaitu beberapa pasien klinik kecantikan tersebut. Dengan melakukan penelitian di lokasi tersebut, akan sangat memudahkan untuk meng-akses data demi keakuratan penyusunan penelitian ini.

Data yang akan dikumpulkan adalah data primer, yang diperoleh langsung dari lapangan dengan cara melakukan wawancara kepada pelaku usaha yaitu klinik kecantikan yang ada di Karawang. Selain pihak pelaku usaha di atas, penulis juga melakukan penelitian pada pihak konsumen yaitu beberapa pasien klinik kecantikan tersebut. Data sekunder, UUD RI 1945, Kitab Undang-undang Hukum Perdata, Undang-undang No. 8 Tahun 1999 tentang Perlindungan Konsumen, Undang-undang No. 36 Tahun 2009 tentang Kesehatan, Peraturan Pemerintah No. 72 Tahun 1998 tentang Pengamanan Sediaan Farmasi dan Alat Kesehatan, Peraturan Menteri Kesehatan Republik Indonesia Nomor 1175/MENKES/PER/ VII/2010 tentang Izin Produksi kosmetika, Peraturan Menteri Kesehatan No. 9 tahun 2014 Tentang Klinik, Keputusan Kepala BPOM No. HK.00. 05.4.1745 tentang Kosmetik, Peraturan Kepala Badan Pengawas Obat dan Makanan Republik Indonesia (BPOM) No. HK.00.05.42. 2995 tentang Pengawasan Pemasukan Kosmetik, dan data tersier, yaitu literatur, dokumen berupa kartu pasien dan rekam medis dari pasien yang melakukan perawatan di klinik kecantikan.

Untuk memperoleh data yang dibutuhkan guna melengkapi penelitian yang dilakukan, maka penulis mempergunakan teknik pengumpulan data yang terbagi atas, wawancara yang dipahami sebagai suatu teknik 
pengumpulan data dengan mengajukan pertanyaan langsung kepada responden, yang terdiri dari pihak pelaku usaha yaitu klinik kecantikan yang ada di Karawang, serta konsumen yaitu beberapa pasien klinik kecantikan tersebut, dan studi pustaka, dalam teknik pengumpulan data ini merupakan jenis data sekunder yang digunakan unutuk membantu proses penelitian, yaitu dengan mengkaji dan menganalisis literature peraturan perundangundangan, serta datum lainnya yang berkaitan dengan masalah yang dibahas dalam penelitian ini.

Populasi dan sampel populasi dalam penelitian ini meliputi klinik kecantikan sebagai pelaku usaha, serta pasien klinik kecantikan sebagai konsumen yang ada di Karawang, sedangkan sampel dalam penelitian ini ditetapkan dengan teknik sampling random yaitu dengan cara menetapkan jumlah kriteria sampel yang ditetapkan oleh peneliti dengan jumlah yang terbatas. Adapun sampel peneliti terdiri dari pelaku usaha, yaitu klinik kecantikan dan 10 pasien klinik kecantikan yang ada di Karawang.

Metode analisis data yang digu-nakan adalah metode kualitatif, yaitu analisis yang memadukan data berupa hasil pengamatan, wawancara, bahan tertulis berupa buku-buku terkait dengan penelitian ini, perlindungan konsumen, kesehatan kecantikan, pengaman sediaan farmasi dan alat kesehatan, izin produksi kosmetika peraturan klinik, yang kemudian dianalisis secara deskriptif yang akan memberikan gambaran yang menyeluruh mengenai permasalahan yang diteliti, mencari pemecahan, dan menarik kesimpulan, maka dapat diperoleh suatu hasil yang menggambarkan perlindungan hukum terhadap konsumen dari praktik klinik kecantikan ilegal di Karawang.

\section{PEMBAHASAN}

Saat ini telah terjadi perubahan pola perilaku interaksi antara penyedia jasa dan penerima jasa kesehatan. Orang yang datang ke dokter dan ke klinik bukan lagi semata-mata karena menderita suatu penyakit melainkan hanya untuk mempercantik diri melalui perawatan tubuh dari ujung kepala hingga ujung kaki. Terjadi pergeseran orientasi, dari pelayanan kesehatan beralih ke industri kesehatan. Industri kesehatan ini pun semakin berkembang pesat akibat kemajuan teknologi kedokteranyang canggih seperti alat suntik, laser, alat mesotherapy, dan galvanic yang mana hal tersebut juga merupakan salah satu daya tarik bagi konsumen yang ingin melakukan perawatan kesehatan kulit atau kecantikan di klinik kecantikan.

Klinik adalah fasilitas pelayanan kesehatan yang menyelenggarakan pelayanan kesehatan perorangan yang menyediakan pelayanan medis dasar dan/atau spesialistik, diselenggarakan oleh lebih dari satu jenis tenaga kesehatan (perawat dan atau bidan) dan dipimpin oleh seorang tenaga medis (dokter, 
dokter spesialis, dokter gigi atau dokter gigi spesialis). ${ }^{5}$

Klinik merupakan organisasi kese-hatan yang bergerak dalam penyediaan pelayanan kesehatan kuratif (diagnosis dan pengobatan), biasanya terhadap satu macam gangguan kesehatan. ${ }^{6}$ Klinik kecantikan dapat dipersamakan dengan fasilitas pelayanan kesehatan lainnya seperti rumah sakit, puskesmas dan lain-lain yang merupakan tempat penyelenggaraan upaya pelayanan kesehatan yang dapat digunakan untuk pelayanan kesehatan kulit atau dermatologi. Klinik kecantikan terdiri dari klinik utama dan klinik pratama. Perbedaan mendasar dari klinik utama dan pratama terletak pada penanggung jawab dan pelayanan kesehatan yang dapat dilakukan dalam masing-masing klinik.

Salah satu jasa yang ditawarkan dalam klinik kecantikan adalah jasa perawatan tubuh atau kulit yang menggunakan kosmetika dan peralatan kesehatan yang ditunjang dengan menggunakan teknologi laser yang canggih. Pelaku usaha dan konsumen memiliki hubungan saling membutuhkan dalam kegiatan bisnis. Pelaku usaha memiliki kepentingan untuk memperoleh laba (profit), sedangkan konsumen memiliki kepentingan untuk memperoleh kepuasan melalui pemenuhan kebutuhannya terhadap produk/jasa tertentu. Dalam hubungan yang demikian seringkali terjadi ketidakseimbangan antara keduanya.

Posisi konsumen sebagai pihak yang paling lemah menjadi sasaran eksploitasi dari pelaku usaha yang secara sosial dan ekonomi mempunyai posisi yang kuat. Dengan perkataan lain, konsumen adalah pihak yang rentan mengalami kerugian akibat produk atau jasa yang ditawarkan oleh pelaku usaha. Kerugian-kerugian yang dialami oleh konsumen tersebut dapat timbul sebagai akibat dari adanya hubungan hukum perjanjian antara pelaku usaha/produsen dengan konsumen, maupun akibat dari adanya perbuatan melanggar hukum yang dilakukan oleh produsen. $^{7}$

Adapun Kewajiban pelaku usaha untuk beritikad baik dalam menjalankan usahanya sebenarnya telah diatur oleh UU PK. Pasal 7 huruf a UU PK menyebutkan bahwa kewajiban pelaku usaha adalah beritikad baik dalam melakukan kegiatan usahanya. Namun, pada kenyataannya masih banyak pelaku usaha yang tidak beritikad baik dalam menjalankan usahanya.

Perlindungan hukum sangat penting bagi tenaga kesehatan dan konsumen dalam hubungan pemberian layanan kesehatan. Hal tersebut disebabkan karena adanya benturan kepentingan sebagai akibat tindakan tenaga

\footnotetext{
5 Dinas Kesehatan Lamongan, Pengertian dan Jenis Klinik, https://lamongankab.go.id/dinkes/pengertian-danjenis-klinik/, 23 Oktober 2018, 13. 30 WIB.

6 Kamus Bahasa Indonesia Edisi Empat, Jakarta: Gramedia, hlm. 708

7 Ahmadi Miru, Prinsip-Prinsip Perlindungan Hukum Bagi Konsumen Di Indonesia, Jakarta: RajawaliPers, 2011, hlm. 1.
} 
kesehatan terhadap pemakai jasa layanan kesehatan dan pemeliharaan kesehatan konsumen. Adapun yang dimaksud dengan tenaga kesehatan adalah setiap orang yang mengabdikan diri dalam bidang kesehatan serta memiliki pengetahuan dan/atau keterampilan melalui pendidikan di bidang kesehatan yang untuk jenis tertentu memerlukan kewenangan untuk melakukan upaya kesehatan.

Janus Sidabalok mengemukakan 4 (empat) alasan pokok mengapa konsumen perlu dilindungi, yaitu:

1. Melindungi konsumen sama artinya dengan melindungi seluruh bangsa sebagaimana diamanatkan oleh tujuan pembangunan nasional menurut UUD 1945;

2. Melindungi konsumen perlu untuk menghindarkan konsumen dari dampak negatif penggunaan teknologi;

3. Melindungi konsumen perlu untuk melahirkan manusia-manusia yang sehat rohani dan jasmani sebagai pelaku-pelaku pembangunan, yang berarti juga untuk menjaga kesinambungan pembangunan nasional;

4. Melindungi konsumen perlu untuk menjamin sumber dana pembangunan yang bersumber dari masyarakat konsumen. ${ }^{8}$

Perlindungan hukum bagi konsumen berarti bicara mengenai hak-hak konsumen. Hak-hak konsumen sudah secara jelas dan terinci diatur dalam UU PK, hanya saja dalam prakteknya hak-hak tersebut kerapkali diabaikan karena itikad yang tidak baik dari pelaku usaha dalam menjalankan usaha nya.

Penggunaan kosmetika dan alat kesehatan tanpa izin edar oleh klinik kecantikan diduga menjadi penyebab dari kerugian yang dialami oleh konsumen.Perlindungan hukum terhadap konsumen dari peredaran sediaan farmasi berupa kosmetika dan alat kesehatan tanpa izin edar oleh klinik kecantikan illegal sebenarnya telah diatur dalam UU Kesehatan dan UU PK. Pasal 4 UU Kesehatan menyebutkan bahwa setiap orang berhak atas kesehatan. Penjelasan dari Pasal ini menjelaskan bahwa hak atas kesehatan yang dimaksud adalah hak untuk memperoleh pelayanan kesehatan dari fasilitas pelayanan kesehatan (termasuk klinik kecantikan) agar dapat mewu-judkan derajat kesehatan yang setinggi-tingginya. Adapun Pasal 5 ayat (2) UU Kesehatan juga menyebutkan bahwa setiap orang mempunyai hak dalam memperoleh pelayanan kesehatan yang aman, bermutu, dan terjangkau.

Sehubungan dengan peredaran sediaan farmasi dan alat kesehatan, Pasal 106 UU Kesehatan dan Pasal 9 ayat (1) PP Tentang Pengamanan Sediaan Farmasi dan Alat Kesehatan mengatakan bahwa sediaan farmasi dan alat kesehatan yang diedarkan harus memiliki Izin edar. Selain itu, Pasal 22 PP

\footnotetext{
8 Janus Sidabalok, 2010, Hukum Perlindungan Konsumen di Indonesia, Bandung: Citra Aditya Bakti, hlm. 6.
} 
Tentang Pengamanan Sediaan Farmasi dan Alat Kesehatan juga mengatur bahwa sediaan farmasi dan alat kesehatan yang dikeluarkan atau dimasukkan ke dalam wilayah Indonesia dengan tujuan untuk diedarkan maka terlebih dahulu harus disertai Izin edar dari lembaga yang berwenang.

Perlindungan hukum terhadap konsumen telah diatur dalam Pasal 4 UU PK yang mengatakan bahwa konsumen memiliki hak atas kenyamanan, keamanan, keselamatan dalam mengkonsumsi barang dan/atau jasa. Selain itu, Pasal 8 ayat (1) huruf a UU PK juga menerangkan bahwa pelaku usaha dilarang memproduksi dan/atau memperdagangkan barang dan/atau jasa yang tidak memenuhi atau tidak sesuai dengan standar yang dipersyaratkan dalam ketentuan peraturan perundang-undangan.

Dalam kasus ini, dokter pada klinik kecantikan illegal yang sekaligus adalah pemilik dari Klinik illegal tersebut telah melanggar kewajibannya untuk menjamin hak atas keamanan dan keselamatan konsumen dalam mengkonsumsi barang dan/atau jasa dengan menggunakan dan/atau memperdagangkan kosmetika dan alat kesehatan yang tidak memenuhi standar yang telah diatur dalam peraturan perundang-undangan. Dokter tersebut, sebagai pelaku usaha telah memperdagangkan dan juga menggunakan kosmetika dan alat kesehatan yang tidak memiliki izin edar dari BPOM dan Kementerian Kesehatan.

Kosmetika tanpa izin edar adalah kosmetika yang tidak didaftarkan oleh pelaku usaha ke BPOM untuk mendapatkan izin edar yang berupa notifikasi BPOM. Notifikasi sendiri merupakan bentuk peraturan baru dari BPOM yang harus ditaati pelaku usaha. Adapun alat kesehatan tanpa izin edar adalah alat kesehatan yang tidak didaftarkan oleh pelaku usaha ke Direktorat Jenderal Kefarmasian dan Alat Kesehatan, Kementerian Keseha-tan Republik Indonesia. Izin edar diperlukan karena dengan adanya izin edar pada kosmetika dan alat kesehatan menandakan bahwa kosmetika dan alat kesehatan tersebut telah dinyatakan lulus dari beberapa tahapan yang ditentukan dari pihak BPOM dan Kementerian Kesehatan sehingga aman untuk dikonsumsi oleh konsumen. Adapun tahapan tersebut dapat berupa uji laboratorium terkait dengan proses produksi, pengemasan, serta kandungan dari bahan yang digunakan untuk kosmetika tersebut dan untuk alat kesehatan, diperlukan penandaan terkait dengan kegunaan dan cara pemakaian dari alat kesehatan tersebut. ${ }^{9}$

Apabila hasil uji laboratorium menunjukkan bahwa kandungan dari bahan kosmetika dan kegunaan dari alat kesehatan tersebut aman untuk dikonsumsi masyarakat, maka BPOM akan mengeluarkan izin edar berupa

\footnotetext{
${ }^{9}$ www.pom.go.id, Diakses pada 12 November 2018, Pukul 10.30 WIB.
} 
notifikasi untuk kosmetika dan penandaan atau izin edar untuk alat kesehatan.

Kosmetika dan alat kesehatan yang telah memenuhi izin edar dipastikan sudah aman untuk dikonsumsi oleh masyarakat. Adapun yang berhak mendaftarkan kosmetika di wilayah Indonesia adalah produsen kosmetik yang mendapat izin usaha Industri, perusahaanyang bertanggung jawab atas pemasaran dan badan hukum yang ditunjuk atau diberi kuasa oleh perusahaan dari negara asal.

Pada kenyataannya, masih saja terdapat pelaku usaha yang tidak mendaf-tarkan kosmetika dan alat kesehatan yang digunakan dan/atau diedarkan kepada konsumen seperti yang dilakukan oleh dokter klinik kecantikan illegal yang ada di Karawang. Pelaku usaha cenderung melakukan perbuatan yang melanggar undang-undang dikarenakan persaingan usaha khususnya dalam industri kecantikan yang bertumbuh sangat pesat. Pelaku usaha cenderung mencari berbagai macam cara untuk mendapatkan keuntungan yang sebesar-besarnya. Salah satu caranya adalah dengan menjual kosmetika dengan harga yang lebih murah dibandingkan dengan pelaku usaha lain. Adapun cara untuk menjual kosmetika dengan harga yang lebih murah tersebut dilakukan dengan memasukkan kosmetika dan alat kesehatan dari luar negeri melalui pelabuhan-pelabuhan yang tidak diawasi oleh petugas kepolisian sehingga pelaku usaha tersebut tidak perlu membayar bea masuk. ${ }^{10}$

Tidak adanya bea masuk yang dikenakan terhadap produk tersebutlah yang membuat pelaku usaha dapat menjual produknya lebih murah dibandingkan dengan pelaku usaha yang memasukkan produknya sesuai ketentuan peraturan perundang-undangan.

Dalam kasus ini, tidak didaftar-kannya kosmetika dan alat kesehatan kulit berupa Korean Laser maka kosmetika dan Korean Laser tersebut tidak memiliki izin edar dan berarti juga bahwa standar mutu, keamanan, kemanfaatan dan keselamatan dalam mengkonsumsi produk dan jasa tersebut tidak ada jaminannya.

Pelaku usaha sering menyalahkan birokrasi yang lama dan biaya yang mahal padahalkenyataannya birokrasi sudah dipermudah dengan berbagai macam upaya salah satunya adalah dengan melakukan permohonan penga-juan notifikasi kosmetika secara online. Hal ini dilakukan agar pelaku usaha tidak perlu berulang kali datang ke kantor BPOM. Pelaku usaha hanya perlu melengkapi dokumen-dokumen yang memang diperlukan dan mengisi template yang telah disediakan dalam laman resmi BPOM secara online.

Pelaku usaha yang mengimpor kosmetika dari luar negeri pun telah dipermudah dengan adanya peraturan kepala BPOM yang mengatur bahwa kosmetika yang dimasukkan dari

10 Wawancara terhadap salah satu pihak pelaku usaha yaitu klinik kecantikan yang ada di Karawang, 12 November 2018 . 
luar negeri tidak dilakukan uji laboratorium lagi selama pelaku usaha tersebut dapat menunjukkan dokumen-dokumen yang diperlukan seperti izin edar kosmetika tersebut dari negara yang bersangkutan. Adanya izin edar dari negara yang bersangkutan dianggap sudah menjamin kandungan dari produk yang di import tersebut. Pelaku usaha hanya perlu mendaftarkan kosmetika tersebut untuk mendapatkan notifikasi agar BPOM dapat melakukan pengawasan dan apabila di kemudian hari terdapat konsumen yang melaporkan produk tersebut, maka BPOM dapat mengetahui siapa pelaku usaha dari produk yang dilaporkan tersebut.

BPOM mengalami berbagai macam kendala dalam melakukan pengawasan terhadap kosmetika yang beredar dalam masyarakat. Hal tersebut dikarenakan jumlah dari kosmetika yang sampai ribuan item jenisnya, sehingga tidak memungkinkan bagi BPOM untuk mengawasi satu per satu dari kosmetika tersebut. Kekurangan sumber daya juga menjadi faktor lain yang membuat fungsi pengawasan terhadap peredaran kosmetika oleh BPOM tidak berjalan efektif.

Perlindungan hukum terhadap konsumen yang mengalami kerugian akibat kesalahan atau kelalaian dari tenaga kesehatan yang menggunakan dan/atau mengedarkan kosmetika dan alat kesehatan tanpa izin edar sebenarnya telah diatur dalam UU Kesehatan dan UU PK. Perlindungan hukum tersebut berupa adanya hak untuk menuntut ganti rugi terhadap tenaga kesehatan yang menimbulkan kerugian dalam pelayanan kesehatan kulit yang diterimanya. Selain itu, perlindungan hukum mengenai ganti rugi juga telah diatur di dalam Pasal 4 huruf h UU PK yang mengatakan bahwa konsumen memiliki hak untuk mendapat kompensasi ganti rugi dan/atau penggantian, apabila barang dan/atau jasa yang diterima tidak sesuai dengan perjanjian atau tidak sebagaimana mestinya. Adapun penuntutan ganti rugi tersebut dapat didasarkan pada Pasal 1239 dan Pasal 1365 KUHPerdata mengenai wanprestasi dan perbuatan melawan hukum.

Pasal 9 Permenkes tentang Klinik mengatakan bahwa penanggung jawab klinik harus seorang tenaga medis yang memiliki Surat Izin Praktik (SIP) serta dapat merangkap sebagai pemberi pelayanan. Selain itu, Pasal 12 Permenkes tersebut mengatur bahwa tenaga medis pada klinik pratama yang memberikan pelayanan kedokteran paling sedikit terdiri dari 2 (dua) orang dokter dan/atau dokter gigi sebagai pemberi pelayanan sedangkan tenaga medis pada klinik utama yang memberikanpelayanan kedokteran paling sedikit terdiri dari 1 (satu) orang dokter spesialis dan 1 (satu) orang dokter sebagai pemberi pelayanan.

Klinik kecantikan ilegal ini diketahui memiliki 4 orang tenaga kesehatan yang terdiri dari seorang Dokter sebagai penanggung jawab sekaligus pemilik klinik nya dan 3 orang lagi adalah Perawat yang juga memiliki izin praktik keperawatan. Adapun 
Dokter tersebut diketahui hanya memiliki surat izin praktik kesehatan medis dasar. Hal ini berarti dokter hanya diperbolehkan melakukan praktik medis dasar dan tidak diperbolehkan melakukan operasi khusus karena tidak sesuai dengan izin yang dimilki.

Klinik kecantikan ini telah terbukti melanggar ketentuan dalam Pasal 25 Permenkes tentang Klinik yang menyebutkan bahwa setiap penyelenggaraan klinik wajib memiliki izin praktik dan izin operasional. Adapun klinik kecantikan ini diketahui tidak memiliki izin operasional dan izin praktik sebagaimana yang telah diatur dalam Permenkes tersebut.

Kerugian yang diderita seseorang secara garis besar dapat dibagi atas dua bagian, yaitu kerugian yang menimpa diri dan kerugian yang menimpa harta benda seseorang sedangkankerugian harta benda sendiri dapat berupa kerugian nyata yang dialami serta kehilangan keuntungan yang diharapkan. ${ }^{11} \mathrm{Wa}$ laupun kerugian dapat berupa kerugian atas diri (fisik) seseorang atau kerugian yang menimpa harta benda, namun jika dikaitkan dengan ganti kerugian, maka keduanya dapat dinilai dengan uang (harta kekayaan). Demikian pula karena kerugian harta benda dapat pula berupa kehilangan keuntungan yang diharapkan, maka pengertian kerugian seharusnya adalah berkurangnya/tidak diperolehnya harta kekayaan pihak yang satu, yang disebabkan oleh perbuatan (melakukan atau membiarkan) yang melanggar norma oleh pihak lain.

Klinik kecantikan wajib melakukan penanganan apabila ada konsumen yang mengeluh akibat menggunakan jasa maupun produk kosmetika dan alat kesehatan dari klinik yang bersangkutan. Penanganan tersebut dapat berupa pengamatan produk yang di edarkan. Jika ada masyarakat yang melaporkan suatu produk terkait dengan mutu dan keamanannya, maka keluhan dan laporan masyarakat tersebut hendaknya dicatat, diperiksa, dievaluasi, dan ditindaklanjuti. Kosmetik yang terbukti menimbulkan efek samping yang merugikan harus ditarik dari peredaran dan dimusnahkan.

Pasal 4 huruf e UU PK menyebutkan bahwa konsumen memiliki hak untuk mendapatkan upaya penyelesaian hukum yang patut. Upaya penyelesaian hukum yang patut ini dilakukan apabila pelaku usaha menolak atau tidak memenuhi kewajiban hukum nya untuk membayar ganti rugi yang dituntut oleh konsumen. Selain itu UU PK juga mengatur mengenai jalur penyelesaian sengketa yaitu dalam Pasal 45 ayat (1), dimana menurut Pasal tersebut penyelesaian sengketa dapat melalui lembaga yang bertugas menyelesaikan sengketa antara konsumen dan pelaku usaha yang dikenal dengan nama Badan Penyelesaian Sengketa Konsumen

11 Ahmadi Miru Yodo Sutarman, Op. Cit. hlm. 133. 
(BPSK) atau melalui peradilan yang berada di lingkungan peradilan umum.

BPSK sebenarnya menjadi alternatif bagi kejenuhan dan keprihatinan masyarakat terhadap sistem peradilan di Indonesia yang dianggap menyita waktu yang lama dan juga biaya yang mahal. Salah satu tugas dari BPSK menurut Pasal 52 UU PK adalah melaksanakan penanganan dan penyelesaian sengketa konsumen dengan cara konsiliasi, mediasi, dan arbitrase. Apabila di kemudian hari dokter tersebut terbukti bersalah dan tidak bersedia membayar ganti rugi sesuai dengan tuntutan komsun, maka konsumen memiliki hak untuk memilih menyelesaikan sengketa nya apakah melalui BPSK atau peradilan umum.

Pasal 13 Peraturan Konsil Kedokteran Indonesia Nomor 16 Tahun 2006 Tentang Tata Cara Penanganan Kasus Dugaan Pelanggaran Disiplin Dokter dan Dokter Gigi oleh Majelis Kehormatan Disiplin Kedokteran Indonesia dan Majelis Kehormatan Disiplin Kedokteran Indonesia di Tingkat Provinsi, pemeriksaan dokter yang diadukan oleh pasien atau konsumen dilakukan dalam bentuk sidang Majelis Pemeriksa Disiplin. Jika dokter yang diadukan tebukti bersalah maka dokter tersebut akan diberi sanksi disiplin berupa pemberian peringatan tertulis, rekomendasi pencabutan Surat Tanda Registrasi atau Surat Izin praktik serta kewajiban mengikuti pendidikan atau pelatihan di institusi pendidikan kedokteran.
Adapun keputusan Sidang Majelis Pemeriksa Disiplin merupakan keputusan MKDKI yang mengikat Konsil Kedokteran Indonesia, dokter yang diadukan, pengadu, Departemen Kesehatan kabupaten/kota serta institusi terkait. MKDKI hanya berwenang memeriksa dokter yang dianggap telah melakukan kesalahan.

\section{KESIMPULAN}

Perlindungan hukum terhadap konsumen yang mengalami kerugian dari praktik klinik kecantikan illegal yang menyediakan dan/atau mengedarkan sediaan farmasi berupa kosmetika dan alat kesehatan tanpa izin edar diwujudkan dengan adanya pemberian hak untuk menuntut ganti rugi kepada pelaku usaha dan hak atas penyelesaian hukum yang patut baik melalui BPSK maupun melalui peradilan umum apabila pelaku usaha tidak bersedia untuk memberikan ganti rugi sebagaimana telah diatur dalam UU Kesehatan dan UU PK meskipun pada praktiknya masih terdapat kendala berupa pengawasan dari BPOM dan Dinkes yang tidak optimal akibat kurangnya sumber daya manusia di lembaga tersebut.

\section{DAFTAR PUSTAKA}

\section{Buku}

Ahmadi Miru Yodo Sutarman, Hukum Perlindungan Konsumen, Cetakan ke 6, Jakarta: Raja Grafindo Persada, 2010. 
Ahmadi Miru, Prinsip-Prinsip Perlindungan Hukum Bagi Konsumen Di Indonesia, Jakarta : RajawaliPers, 2011.

Ahmadi Miru dan Sutarman Yodo, Hukum Perlindungan Konsumen, Jakarta: Raja Grafindo Persada, 2011.

Basu Swastha dan Hani Handoko, Manajemen Perusahaan Analisa Perilaku Konsumen, Yogyakarta: Liberty Edisi Pertama.

Janus Sidabalok, Hukum Perlindungan Konsumen di Indonesia, Bandung: Citra Aditya Bakti, 2010.

\section{Peraturan Perundang-undangan}

Undang-Undang Dasar 1945 Amandemen ke 4

Kitab undang-undang Hukum Perdata (KUHPerdata)

Undang-Undang No.8 Tahun 1999 Tentang Perlindungan Konsumen

Undang-Undang No.36 tahun 2009 tentang Kesehatan,

Peraturan Pemerintah Nomor 72 Tahun 1998 tentang Pengamanan Sediaan Farmasi dan Alat Kesehatan

Peraturan Menteri Kesehatan Republik Indonesia Nomor 1175/MENKES/PER/ VII/2010 tentang Izin Produksi kosmetika

Peraturan Menteri Kesehatan No.9 Tahun 2014 Tentang Klinik

Keputusan Kepala BPOM Nomor HK.00.05.4.1745 tentang Kosmetik

Peraturan Kepala Badan Pengawas Obat dan Makanan Republik Indonesia (BPOM) Nomor HK.00.05.42.2995 Tentang Pengawasan Pemasukan Kosmetik

\section{Internet}

Olivia, Definisi Kecantikan, http://digilib.unila.ac.id/11921/16/BA
B\%20II.pdf, 23 Oktober 2018, pukul 13.12 WIB.

Dinas Kesehatan Lamongan, Pengertian dan Jenis Klinik, https://lamongankab.go.id/dinkes/pen gertian-dan-jenis-klinik/, 23 Oktober 2018, 13. 30 WIB. 